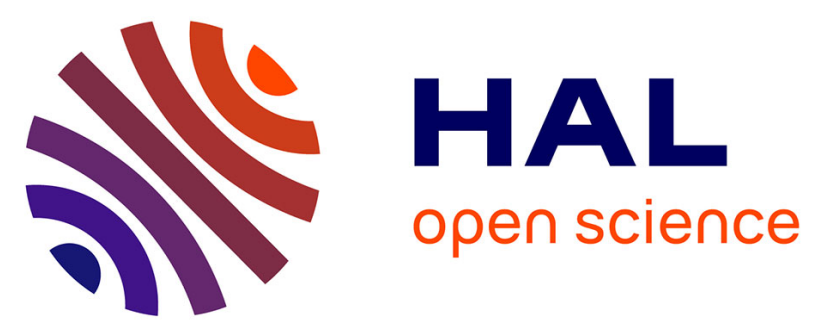

\title{
Sustainability of Meat Chain: The Carbon Footprint of Brazilian Consumers
}

Raquel Silva, João Reis, Thayla Carvalho Curi, Nilsa Lima, Solimar Garcia, Irenilza De Alencar Nääs

\section{- To cite this version:}

Raquel Silva, João Reis, Thayla Carvalho Curi, Nilsa Lima, Solimar Garcia, et al.. Sustainability of Meat Chain: The Carbon Footprint of Brazilian Consumers. IFIP International Conference on Advances in Production Management Systems (APMS), Sep 2019, Austin, TX, United States. pp.102107, 10.1007/978-3-030-30000-5_13 . hal-02419225

\section{HAL Id: hal-02419225 \\ https://hal.inria.fr/hal-02419225}

Submitted on 19 Dec 2019

HAL is a multi-disciplinary open access archive for the deposit and dissemination of scientific research documents, whether they are published or not. The documents may come from teaching and research institutions in France or abroad, or from public or private research centers.
L'archive ouverte pluridisciplinaire HAL, est destinée au dépôt et à la diffusion de documents scientifiques de niveau recherche, publiés ou non, émanant des établissements d'enseignement et de recherche français ou étrangers, des laboratoires publics ou privés. 


\title{
Sustainability of meat chain: The carbon footprint of Brazilian consumers
}

\author{
Raquel Baracat T. R. Silva ${ }^{1 *[0000-0001-7184-8162]}$, João Gilberto Mendes Reis ${ }^{1[0000-0001-}$ \\ 6409-2299], Thayla M. R. Carvalho Curi ${ }^{2[0000-0002-2996-4466]}$, Nilsa D. S. Lima ${ }^{3[0000-0002-1284-}$ \\ ${ }^{7810]}$, Solimar Garcia ${ }^{1[0000-0002-5807-8041]}$, \\ and Irenilza de Alencar Nääs 1[0000-0003-0663-9377]. \\ ${ }^{1}$ University Paulista (Unip), São Paulo, Brazil \\ ${ }^{2}$ Faculdade Anhanguera de Campinas, São Paulo, Brazil \\ ${ }^{3}$ University of Campinas (Unicamp), São Paulo, Brazil \\ raquelbaracat@gmail.com
}

\begin{abstract}
The term "carbon footprint" of products refers to the mass of greenhouse gases (GHG) emitted due to the production, use, and disposal of a product. The option of buying food is a complex behavior influenced by different factors that play an essential role in consumer perceptions. The present study aimed to analyze the carbon footprint profile of Brazilian consumers of beef, broiler meat, and vegetarian. A questionnaire was sent by e-mail, and 222 answers were obtained. Three consumer profiles were defined based on the similarities (C0, C1, and C2). The carbon footprint of C0 was $18 \pm 3$ tons/year; the C1 $17 \pm 2$ tons/year; and the group C2 had $18 \pm 3$ tons/year. No difference in the carbon footprint of the meat eaters and vegetarians was found in the clusters studied. The meat consumers and the vegetarians have the same impact on the environment when the WWF calculator is applied.
\end{abstract}

Keywords: Meat Production, Environmental Impact, Meat Supply Chain.

\section{Introduction}

The term "carbon footprint" for products refers to the mass of greenhouse gases (GHG) emitted due to the production, use, and disposal of a product. Thus, studies on product carbon footprint account for emissions from a set of processes related to the life cycle of a product. The proliferation of a wide variety of products, to satisfy the heterogeneity of the tastes of each consumer, do the decision-making process increasingly difficult, which leads to the consumer using mental shortcuts, as is the case of labels and brands, to facilitate decision making [1]. Understanding more clearly, the behavior of the consumer as well as what influences their choices is essential to achieve a way to motivate sustainable consumption.

The choice of buying food is a complex behavior [2] influenced by different factors that play an essential role in consumer expectations and perceptions [3,4]. Some 
consumers become more cautious when they seek safety, high quality [5], authenticity, health, and tradition in their food than others [6]. Therefore, there is an attempt to meet this demand; an in-depth knowledge of consumer behavior is required [7]. Previous studies concluded with the provision of information alone is not enough to encourage a more sustainable purchasing decision because the information is available, but rarely does the consumer seek to read or digest all the information available [1].

Consumers are goods contribute to anthropogenic climate change throughout their product lifecycles through the carbon emissions resulting from the extraction, processing, logistics, and storage of raw materials until their use and disposal [8]. Growing demand for food is a global trend for the coming decades, highlighting the difficulty in supplying food to the global population [9]. The food industry, therefore, assumed a unique situation, driven by unprecedented changes in economic, technological, and social structures. Given these changes, a new pattern of consumption in the population must be recognized to pinpoint the factors that influence behavior.

Meat is one of the essential items of the Brazilian diet, and the domestic market is responsible for the consumption of more than $70 \%$ of the national production [10]. Despite their importance, research aimed at understanding the particularities and determining the consumption pattern of the population is still incipient. How can manufacturers of consumer goods make step-by-step reductions in their product lifecycle carbon emissions by engaging and influencing their key stakeholders?

The Brazilian government has been encouraging the adoption of measures to reduce GHG emissions in all productive sectors, especially agriculture. At the end of 2009, the National Policy on Climate Change was established [11], which instigated the various sectors of the economy to research, develop, and adopt low carbon technologies [12]. According to the Interministerial Committee on Climate Change $[12,13]$, low-carbon agriculture is related to the adoption of processes aimed at pasture recovery, crop-livestock integration, no-tillage, biological nitrogen fixation, and planted forests. This same committee set emission reduction targets of between 5\% and $6 \%$ for the agricultural sector, considering the emission forecast for 2020.

The present study aimed to analyze the carbon footprint profile of Brazilian consumers of beef, broiler meat, and vegetarian and to evaluate the sustainability of these consumers.

\section{Material and Methods}

A total of 222 subjects from different regions of the countries responded to an online questionnaire containing some issues related to consumption habits, including daily consumption of broiler meat, beef, and non-meat. The consumer profile included questions related to age, education, sex, marital status, number of children, type of household, salary, kind of model car, and appropriate actions towards sustainability, such as recycling.

The responses were organized in a database, and the software WEKA ${ }^{\circledR}$ version 3.6.13 [14] was used to divide the data into three groups. The algorithm applied was the Simple K-means using the Euclidean distance to select the categories considering cross-validation samples with $10 \%$ of data (10-fold cross-validation), e.g., the initial 
data were randomly partitioned into ten mutually exclusive subsets, each of approximately equal size. Training and testing were performed ten times. For classification, the accuracy of estimation is the overall number of correct classifications from the ten iterations, divided by the total number of instances in the initial data, as suggested [15].

An online questionnaire containing questions related to the topics described below was used in the following categories: age, schooling; sex, marital status, family size, and salary range of the interviewees. Concerning issues related to animal welfare emphasized to the point of knowledge about recycling, savings on purchases, such as pets, clothes, internet, use of lighting and heating at home, and daily use of cars.

The 222 responses of consumers from all Brazilian regions, the database was prepared. It used the data mining technique to discover the variables that will determine consumption patterns, as recommended by [16]. The most extensive group interviewed was characterized between 36-45 years, with higher education. Most were married and childless. The most representative salary range was $\mathrm{R} \$ 5,000.00$ (five thousand reals).

The responses were organized into three profiles pre-defined by the clustering task, and data were analyzed.

\section{Results and Discussion}

Three clusters were selected (cluster 0 - C0, cluster 1 - C1 and cluster 2 - C2) based on the similarities, such as $69(31 \%), 61(27 \%)$ and $92(41 \%)$ for C0, C1, and C2, respectively. The sum of the square errors was 461.30 in five interactions. Five individuals from each group were randomly selected, and the baseline data were used as input to WWF's online footprint calculator. Table 1 summarizes the results found. The C0 profile was individuals ranging from 26 to 35 years of age, university education, mostly female, single, and she had no children. The carbon footprint of C0 was $18 \pm 3$ tons/year. The $\mathrm{C} 1$ profile had individuals over 45 years old, with a university degree, mainly female, married, and with two or more children.

Table1: Carbon Footprint results of consumer's broiler, beef, and vegetarians

\begin{tabular}{|c|c|c|c|c|c|c|c|c|}
\hline \multicolumn{9}{|c|}{ Carbon footprint ( $\mathrm{CO}_{2}$-e tons/year) } \\
\hline \multicolumn{3}{|c|}{ Broiler consumer } & \multicolumn{3}{|c|}{ Beef consumer } & \multicolumn{3}{|c|}{ Vegetarians consumer } \\
\hline Cluster 0 & Cluster 1 & Cluster 2 & Cluster 0 & Cluster 1 & Cluster 2 & Cluster 0 & Cluster 1 & Cluster 2 \\
\hline 15.20 & 16.20 & 20.60 & 18.50 & 21.80 & 21.10 & 18.10 & 23.30 & 15.40 \\
\hline 16.70 & 14.80 & 21.00 & 20.10 & 26.30 & 19.40 & 11.50 & 20.60 & 19.90 \\
\hline 19.40 & 19.70 & 20.00 & 21.10 & 21.10 & 15.40 & 13.30 & 20.95 & 23.50 \\
\hline 23.40 & 18.40 & 16.50 & 22.60 & 19.50 & 20.40 & - & - & - \\
\hline 18.70 & 16.70 & 14.20 & 19.40 & 25.70 & 20.80 & 14.30 & 21.62 & 19.60 \\
\hline \multicolumn{9}{|c|}{ Mean \pm Standard Deviation } \\
\hline $18.7 \pm 3.1$ & $17.2 \pm 1.9$ & $18.5 \pm 3.0$ & $20.3 \pm 1.6$ & $22.9 \pm 3.0$ & $19.4 \pm 2.3$ & $14.3 \pm 3.4$ & $21.6 \pm 1.5$ & $19.6 \pm 4.0$ \\
\hline
\end{tabular}


The data indicate that the carbon footprint is a function of the option of consuming beef, poultry or neither (either most of the meals with beef or chicken or without the consumption of them), as well as the life and the profile of people grouped in cluster 0 , cluster 1 and cluster 2 (Figure 1). The choice of consumers is coherent with the findings of $[2,3]$. Results may serve as a basis to reduce the carbon footprint of consumers, as proposed by [8].

Carbon footprint results of chicken, beef, and vegetarian meat consumers show a standard behavior in the $\mathrm{CO}_{2}$-e emission ratios. The three groups selected (cluster 0 $\mathrm{C} 0$, cluster $1-\mathrm{C} 1$ and cluster 2 - $\mathrm{C} 2$ ) had the same number of similarities, such as 69 $(31 \%), 61(27 \%)$ and $92(41 \%)$ for $\mathrm{C} 0, \mathrm{C} 1$, and C2, respectively.

\section{Carbon footprint $\left(\mathrm{CO}_{2}\right.$-e tons/year)}

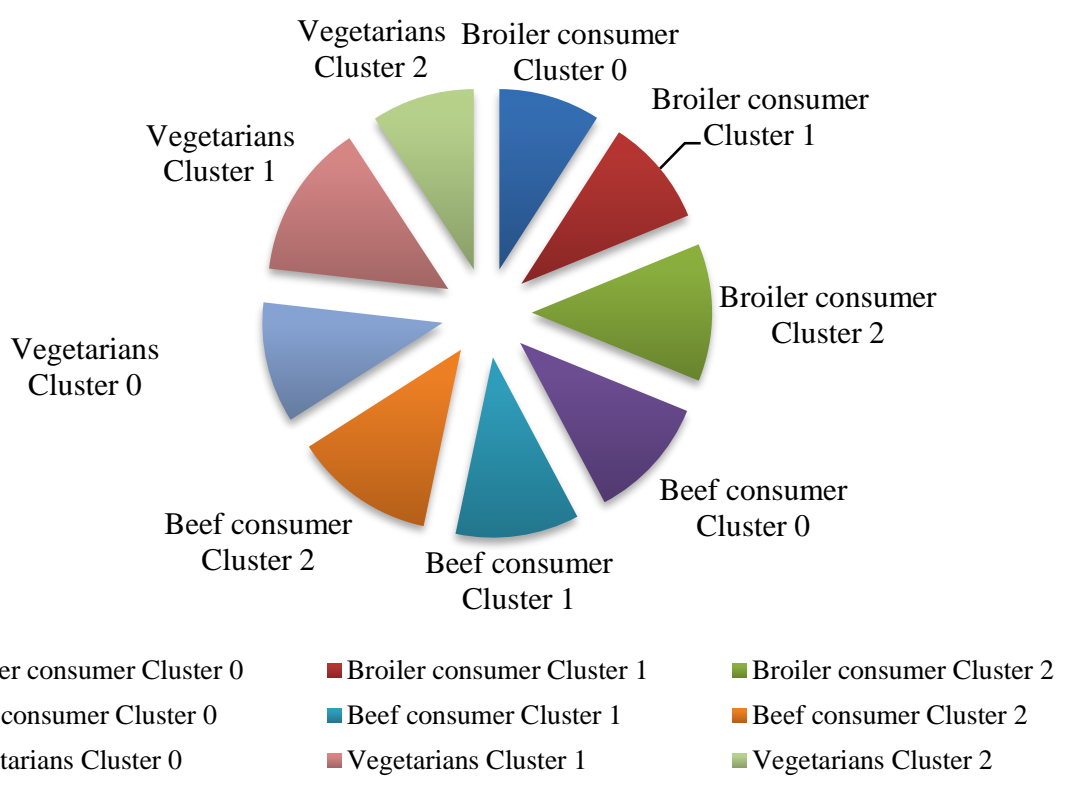

Figure 1 . The scenery of the meat eaters and vegetarians clusters in carbon-equivalent emission.

The sum of the square errors was 461.30 in five interactions. Five individuals from each group were randomly selected, and baseline data were used as input to WWF's online footprint calculator. In this case, the sum of the quadratic error was 557.91 for the division of the database of the individuals interviewed in three different profiles.

Beef consumers showed a high carbon footprint, mainly the Cluster 1 (Figure 2), followed from the mean value of broiler meat eaters, and the vegetarians. Similar profiles were suggested by [7]. 
Clusters of consumers broiler, beef and vegetarians $\left(\mathrm{CO}_{2}\right.$-e tons/year)

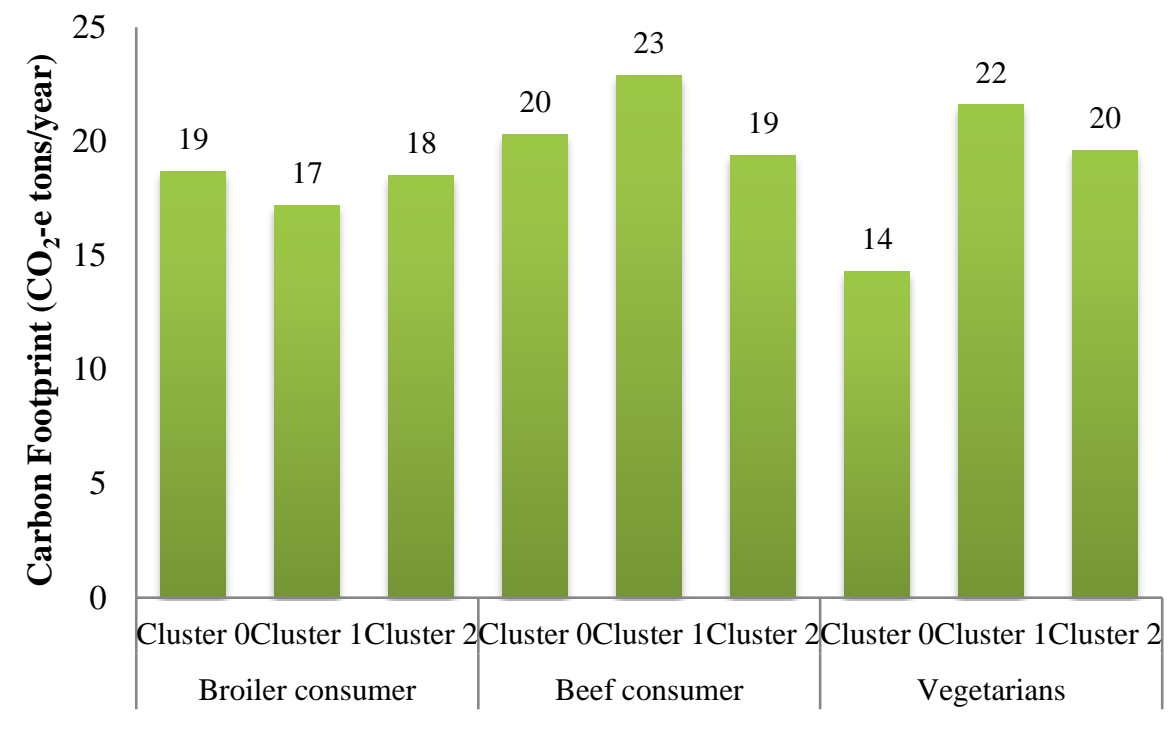

Consumers

Figure 2. The carbon footprint of the clusters studied from broiler meat and beef eaters, and vegetarians.

\section{Final remarks}

Note the importance of consumer influence in the market. Award to a survey by [17], about $8 \%$ of Brazilians declared vegetarians, representing around 15 million consumers. Amongst the reasons for the exemption of meat in the diet, there is the poor condition of the production systems in which animals are reared. That may concern about the environment and health issues, but even the profile of the consumer being vegetarian their lifestyle in Brazil is still the same concerning sustainability and carbon footprint. There are still no consumer concerns with decreased green energy consumption, with reduced car pollution or savings on shopping with clothes, internet, pets, among others.

Acknowledgment: The authors wish to thank CAPES and CNPQ and Paulista University.

\section{References}

1. Alves, A. F.P. O papel do consumidor nas políticas de sustentabilidade. Lisboa, 2012. Dissertação (Mestrado em Engenharia do Ambiente, Perfil de Gestão e Sistemas Ambientais) Faculdade de Ciências e Tecnologia, FCT, Universidade Nova Lisboa, September 2012. 
2. Shepherd, R.; Sparks, P.; Bellier, S. and Raats, M.M. The effects on information on sensory ratings and preferences: The importance of attitudes. Food Qual. Prefer. 3:147-155, 1991. doi: 10.1016/0950-3293(91)90051-F.

3. Chiou, W.B.; Yeh, L. and Chang, M. Effects of health-related claims on the differential threshold of consumers' sweetness sensation. J. Sens. Stud. 24: 621-633, 2009. doi: 10.1111/j.1745-459X.2006.00078.x.

4. Silva, R. B.T.R. da. Itens normativos de bem-estar animal e a produção brasileira de frangos de corte. Campinas-SP, 2012. Tese (Doutorado em Engenharia Agrícola) Faculdade de Engenharia Agrícola - FEAGRI, Universidade Estadual de Campinas - UNICAMP, 17/10/2012.

5. Abreu, D.A.P.; Cruz, J.M. and Losada, P.P. Active and intelligent packaging for the food industry. Food Rev. Intern. 28:146-187, 2012. doi: 10.1080/87559129.2011.595022.

6. Ilbery, B. and Kneafsey, M. Producer constructions of quality in regional speciality food production: a case study from South-west England. J. Rur. S. 16:217-30, 2000. doi: 10.1016/S0743-0167(99)00041-8.

7. Kopetz, C.E.; Kruglanski, A.W.; Arens, Z.G.; Etkin, J. and Johnson, H.M. The dynamics of consumer behavior: a goal systemic perspective. J. Cons. Psyc. 22:208-223, 2012. doi: 10.1016/j.jcps.2011.03.001.

8. Bokken, N.M.P.; Allwood, J.M. Strategies to reduce the carbon footprint of consumer goods by influencing stakeholders. J. Clean. Prod. 35:118-129, 2012. doi: 10.1016/j.jclepro.2012.05.031.

9. FAOSTAT - Food and Agriculture Organization of the United Nations. Statistical database, 2013. Available at: 〈http://www.fao.org/faostat/en/\#data/CP/>. Accessed on Jan. 11, 2019.

10. IBGE - Instituto Brasileiro de Geografia e Estatística. 2013. POF (Pesquisa de Orçamentos Familiares), ftp://ftp.ibge.gov.br/Perfil_Municipios/2012/munic2012.pdf. Accessed on Jan. 12, 2019.

11. Brasil. LEI n. 9.605/98, de 12 de fevereiro de 1998. Dispõe sobre sanções penais e administrativas derivadas de condutas e atividades lesivas ao meio ambiente, e dá providências. In: BRASIL. Constituição Federal: código penal, código de processo penal/ organizador Luiz Flavio Gomes - 3 eds. rev. atual e ampl - São Paulo: Editora Revista dos Tribunais, 2001 - (RT - mini- códigos).

12. Brasil. Lei n. 12.187, de 29 de dezembro de 2009. Institui a Política Nacional sobre Mudança do Clima - PNMC e dá outras providências. Diário Oficial [da] República Federativa do Brasil, Brasília, DF, 29 dez. 2009, http://www.planalto.gov.br/ccivil_03/_ato20072010/2009/lei/112187.htm. Accessed on Jan. 30, 2019.

13. Andrew, R.M., Davis, S.J., Peters, G.P. Climate policy and dependence on traded carbon. Environ. Res. Lett. 8(3): 034011, 2013. doi: 10.1088/1748- 9326/8/3/034011.

14. Frank E., Hall M.A., and Witten I.H. The WEKA Workbench. Online Appendix for Data Mining: Practical Machine Learning Tools and Techniques, Morgan Kaufmann, $4^{\text {th }}$ Edition, 2016.

15. Han, M. Kamber, J. Pei Data mining: Concepts and Techniques, Morgan Kaufmann Publishers, San Francisco, CA, USA, 2011. 
16. Chapman, P.; Clinton, J., Kerber, R., Khabaza, T., Reinartz, T., Shearer, C., Wirth, R. (2000). CRISP-DM 1.0 Step-by-step data mining guide, 2000. CRISP-DM Consortium, http://www. http://www.sciepub.com/reference/80444. Accessed on Jan. 27, 2019.

17. Ibope - Instituto Brasileiro de Opinião Pública e Estatística. Dia Mundial do Vegetarianismo: $8 \%$ da população brasileira afirma ser adepta do estilo, http://www.ibope.com.br/pt-br/noticias/paginas/dia-mundial-do-vegetarianismo-8-dapopulacao-brasileira-afirma-ser-adepta-ao-estilo.aspx. Accessed on Jan. 24, 2019. 